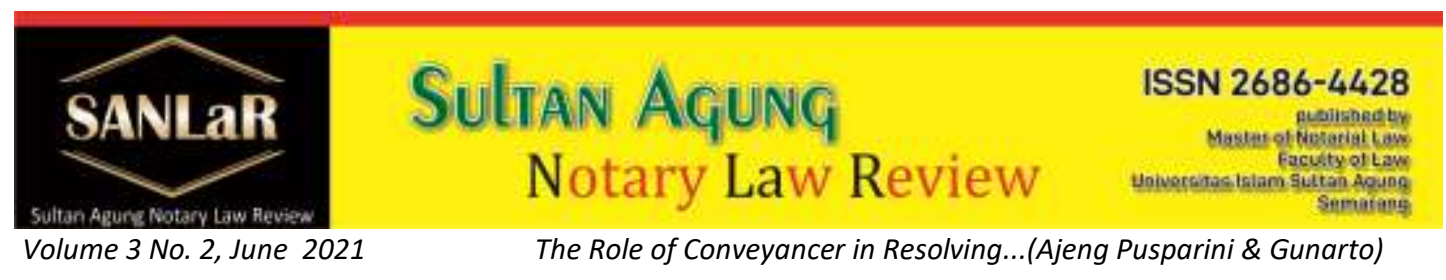

\title{
The Role of Conveyancer in Resolving Disputes against the Deed
}

\author{
Ajeng Pusparini ${ }^{*}$ and Gunarto**) \\ *) Faculty of Law, Universitas Islam Sultan Agung (UNISSULA) Semarang, E-mail: \\ ajengrin0607@gmail.com \\ *) Faculty of Law, Universitas Islam Sultan Agung (UNISSULA) Semarang, E-mail: \\ gunarto@unissula.ac.id
}

\begin{abstract}
Dispute and land conflict is a form of problems that are complex and multi-dimensional. In such disputes often involve the Land Deed Official to account for the deed he made, the National Land Agency as a Facilitator in the handling of land disputes involving land deed. Research method used is empirical juridical, the specification of this research uses descriptive method of analysis, the method of data analysis used is using the method of literature research, based on research concluded so that conveyancer can apply the principle of prudence by conducting field checks, that in handling land disputes it takes good faith and each party must be cooperative in the course of mediation.
\end{abstract}

Keywords: Deed; Conveyancer; Dispute Defense.

\section{Introduction}

Land related cases, especially disputes, occur in the community. The longer it gets more complex, this is because the more sophisticated technology inevitably poses problems related to land and Land Rights.

Resolution of the dispute is an important key to closing the occurrence of shocks in people's lives. The purpose of the shock in society is the inconvenience in carrying out activities in daily life so that the resolution of the dispute is very absolute, a civil dispute is a matter that concerns the interests between the individual and the individual concerning personal interests.

Not infrequently in the implementation of Notary Public/Conveyancer to be the parties involved in the settlement of Land Disputes because of the deed made, 
the deed made must be eligible formal in order to be a condition of registration at the Land Office, therefore Notary/The conveyor must apply the principle of prudence so that the deed made does not cause land disputes in the future. As well as the participation of Notary Public/Conveyancer in the settlement of the dispute should be a barometer of accountability to the deed made, and a Notary/Conveyancer must be cooperative in the settlement of land disputes.

Thus the form of government efforts to discipline the administration of land registration both through legislation and government regulations as the implementation but the effort is still not perfect when viewed from the series of land registration. Conveyancer act which is an authentic deed has the absolute power to deal with the things or events mentioned in the deed, then what is proven is the event.

It is already an inherent phenomenon in the history of culture and human civilization, especially since the agrarian period where land resources began to play an important role as a production factor to meet human needs

\section{Research Methods}

This research is a type of empirical juridical research, or so called field research that examines the provisions of applicable laws and what happens in reality. Empirical juridical research is legal research on the application or implementation of normative legal provisions in action on any particular legal event that occurs in society. Or in other words, a study conducted on the actual situation or real circumstances that occur in the community with the intention to know and find the facts and data needed, after the required data collected then leads to the identification of problems that ultimately lead to problems solving.

\section{Results and Discussion}

\subsection{Notary Role in Resolving Land Disputes against Deed}

That the Position Case that occurred in the Cirebon District Land Office is the process of applying for Recognition of Rights An. Iwan Gunawan there are 3 Registrations as follows:

a. Date 4 May 2020 File Number 30007/2020;

b. Dated May 4, 2020 File Number 29951/2020;

c. Dated May 4, 2020 File Number 29951/2020; 
located in Plawad Block Gebang Mekar Village Gebang District. 3 2. That The Process of Applying for Recognition of An Right. Kartini Husband Chart Registration dated March 13, 2020 File Number 12126/2020, located in The Plawad Block of GebangMekar Village, Gebang District. 3. That the Application Process for Recognition of An Rights. Ismet Moraza there are 6 Registrations as follows:

a. Date 05 May 2020 File Number 30506/2020;

b. Date June 23, 2020 File Number 44725/2020;

c. Dated June 23, 2020 File Number 44679/2020;

d. Dated June 23, 2020 File Number 44687/2020;

e. Dated 23 June 2020 File Number 44715/2020; F. June 23, 2020 File Number 44710/2020;

located in Gebang Mekar Village, Gebang District. Objections \& Application for Termination/Delay of Conversion and Issuance Process Certificate as one of the Heirs of Alm. H. Halimudin Hamdi and Hj. WiwiSudantiareDewiYumitri. The implementation of 2 deadlocked mediations at the Cirebon District Land Office; ${ }^{1}$

\subsection{Theoretical Analysis of the Role of Notary Public/Conveyancer in Land Disputes}

Handling Disputes in the Land Office in general or in the Cirebon District Land Office in particular refers to the new rules of candy ATR/BPN No. 21/2020 on Handling and Settlement of Land Cases substitute candy 11 year 2016 on the handling of disputes, the difference in this Ministerial Regulation lies in the specification of the application file attached with proof of ownership or documents that support the problem. In this case notary/conveyancer cooperative in the implementation of Mediation conducted in the Cirebon District Land Office in accordance with the Invitation sent by the Head of the Cirebon District Land Office;

That the deed of Sale and Distribution of Common Rights that is the basis in the registration of the object of land dispute has met the requirements formal and has gone through the verification process by the relevant Official that in fact Only as formal make a deed, do not look further for the circumstances in the field then for the sake of prudence field review should be done to avoid

${ }^{1}$ Interview with Mr. David Agam as head of section for handling problems and land control 
disputes in the future, as a result if there is a dispute in the future is: Deed of sale and purchase etc. problems occur then the head of the office has the right to reject the deed, If there is a court decision will be annulled as the court's decision as the legal action carried out by the conveyancer, If successful against the deed the deed can be canceled if both parties agree, the case of the heirs will not be dated then it will be included in the certificate. Can both parties agree to give, Mediation mostly deadlock based on the intention of both parties in the form of Presence, Solution, Cooperative Agreement of both parties, mutually beneficial solutions to each other.

That in the Land Dispute that occurred in the Cirebon District Land Office the ten deed that became the object of land dispute has been eligible formil namely the Act must be made by (door) or in front of (tenoverstaan) a public official. The Deed shall be made in the form prescribed by the Law, concerning the form determined by UUJN is that the deed consists of the Head of the deed, the Deed Body, the End of the deed. The General Office by or before whom the deed is made, must have the authority to make the deed. One of the conditions that must be met is the authority of the notary concerned to make the deed.

\section{Closing}

In order for Notary Public/Conveyancer to apply the principle of prudence in the making of the deed, in this case the products made are the Deed of Sale and Purchase and Deed of Sharing of Joint Rights. In order for notary public to not only pay attention to the requirements of formal but is expected to jump directly into the space to ensure the object of land to be made deed. In addition, preemptive actions that can minimize the error of the Deed of land owned by PPAT can suggest on each party continue the process after the field map, field maps can be processed and comparative in the deed in the hope that if the land field map has been attached in the deed, it makes it easier for the Land Office to check and prevent double in land registration.

\section{References}

Books:

[1] Abdulkadir, Muhammad, 2004, Hukum dan Penelitian Hukum, Bandung, Citra Aditya Bakti

[2] Arikunto, Suharsimi, 2012, Prosedur Penelitiaan Suatu Pendekatan Praktek, Jakarta, Rineka Cipta

[3] Hadimulyo, "Mempertimbangkan ADR, Kajian Alternatif Penyelesaian Sengketa di Luar Pengadilan" ELSAM: Jakarta. 1997 
[4] Satrio, S 1992, Hukum Waris, Bandung, Alumni

[5] Waluyo, Bambang, 2002, Penelitian Hukum Dalam Praktek, Jakarta, Sinar Grafika

Interview:

Mr. David Agam S.H., as head of section for handling problems and land control of Cirebon District land office 